\title{
The Innovation and development of Rural Revitalization: Agricultural Supply Chain Finance
}

\author{
Chen Zhang ${ }^{1,1 \text { st }}$, Hui $\mathrm{Li}^{2}$, a, 2rd \\ ${ }^{1}$ School of Economics and Management, Lanzhou University of Technology, Lanzhou, China \\ ${ }^{2}$ School of Economics and Management, Lanzhou University of Technology, Lanzhou, China
}

\begin{abstract}
Agricultural supply chain finance provides a feasible supply channel for the fund demand in rural economic development, alleviates the financing difficulties of small and micro enterprises and farmers in rural areas. However, there are also problems such as low standardization of agricultural products, imperfect credit risk system and incomplete information system, which seriously hinder the implementation of Rural Revitalization strategy. Financial product innovation is put forward in this paper, giving play to the role of government-led, perfect the premium subsidy, guarantees subsidy policy, actively into more involved in the main body, using the emerging technology industrialization construction, building ecological system resource sharing, expand the scope of services, to better precision power financial poverty alleviation, finally realizes the Rural Revitalization strategy.
\end{abstract}

\section{INTRODUCTION}

In the modern economic system, the development of agriculture and the income of farmers cannot do without the support o-f finance. However, the enthusiasm of rural areas to prov-ide financial services as a whole is low, especially in po-or areas of financial exclusion problems ${ }^{[1]}$ With the impl-ementation of targeted poverty alleviation policies and thedevelopment of inclusive finance, agricultural supply chainfinance is regarded as a "golden key" to solve the financ-ing difficulties of poor farmers in the context of agricultu-ral supply-side structural reform and rural revitalization. Si-nce the 18th National Congress of the Communist Party ofChina (CPC), the state has introduced the policy of enco-uraging financial services for agriculture, the country-side a-nd farmers, the financial development of agricultural supplychain has ushered in the "east wind" of development. No.1,20142019 , the central, actively promote agricultural financ-e and agricultural insurance product innovation, encourage the establishment of multi-level financial service system, development of supply chain finance, as a new financing model, agricultural supply chain finance to a cer-tain exte$\mathrm{nt}$, alleviate the financing difficulties of agricultu-ral enter-prises and farmers, relieves the problem of rural financial repression.

\section{LITERATURE REVIEW}

Supply chain finance refers to Banks integrating the logistics and capital flows of upstream and downstream small and medium-size enterprise through specific financial models around core enterprises, transforming the uncontrollable risks of a single enterprise in credit into controllable risks of the whole supply chain, and providing financial services to more small and mediumsize enterprise with the lowest financial risks ${ }^{[2]}$, it is the capital flow and ecosphere formed by the commercial credit among the participants of the supply chain. ${ }^{[3]}$ The earliest form of agricultural supply chain finance can be traced back to the "grain warehouse receipt" in Mesopotamia in $2400 \mathrm{BC}^{[4]}$, refers to financial institutions providing financial services based on the commercial relations between different subjects in the agricultural supply chain ${ }^{[5]}$. It is the best way to solve the problems of agriculture, the countryside and farmers. But the enthusiasm of rural areas to provide financial services as a whole is low, especially in poor areas of financial exclusion problems, leading to a high cost of credit, and credit risk control difficulty phen- omenon such as "market failure"[6], and even result in poor areas of peasant household long-term in the vicious circle of poverty financial circle $^{[7]}$, Agricultural supply chain finance as a new financing model effectively alleviate the financing difficulties of agricultural enterprises and farmers, not only expand the inclusive finance channels, also played a perform accurately the effect of poverty alleviation through industrial development ${ }^{[8]}$. The combination of financial and industrial poverty alleviation and the deep participation of poor households in the development of agricultural industry and the sharing of industrial profits will effectively improve the effect of financial targeted poverty alleviation ${ }^{[9]}$, compared with the poor peasant households to financial institutions financing directly, in the industry on the basis of agricultural supply chain financing for poverty alleviation of poverty reduction effect is better ${ }^{[10]}$. To explore how to give full play to the targeted poverty alleviation effect of inclusive finance in the field of "agriculture, the countryside and farmers" with the help of the new format of agricultural supply chain finance will provide new development ideas for the realization of rural revitalization strategy. 


\section{THE CONNOTATION AND CURRENT SITUATION OF AGRICULTURAL SUPPLY CHAIN FINANCE}

China's supply chain finance is booming. According to data from the National Bureau of Statistics of China (Table 1), the net receivables of industrial enterprises above a certain scale have increased from 8.4 trillion yuan in 2012 to 14.3 trillion yuan in 2018, an increase of 1.7 times. China's supply chain financial market has a broad space for development, suitable for capital entry. The scale of supply chain finance market grows rapidly from 2015 to 2019. As shown in Table 2, the scale of China's supply chain finance market reached 14.42 trillion yuan in 2017 , and it is expected that the scale of China's supply chain finance market will reach 27.01 trillion yuan in 2020 , if agricultural supply chain finance accounts for $7.1 \%$ (the value added of the primary industry accounts for the proportion of GDP in 2019), the market size will exceed 1.91 trillion yuan. In the face of broad market potential and favorable policy support, all kinds of capital have entered the rural supply chain finance, promoting the rural market to continue to heat up. As shown in Table 3, since the establishment of statistics on agriculture-related loans in 2007, the total balance of agricultural loans of all financial institutions has increased by $534.4 \%$ in total, with an average annual growth rate of $16.5 \%$ in the past 11 years. The balance of agriculture-related loans increased from 6.1 trillion yuan at the end of 2007 to 32.7 trillion yuan at the end of 2018, increasing its share of all loans from 22 to 24 percent. Direct financing, such as bonds and stocks, has also developed rapidly. The futures market for agricultural products has grown from scratch and is gradually showing its functions. Inclusive finance still has a long way to go.

Although China is a big agricultural country, the longterm decentralized operation mode leads to low agriculturalproduction efficiency, agricultural industrialization is still $i-n$ the early stage of development, insufficient correlationdegree among members of agricultural supply chain, andweak overall capital strength, which hinders the formationof agricultural supply chain finance. When farmers are unable to perform their contracts and default, the core enterprises that provide credit guarantee to farmers will pay theprincipal and interest to financial institutions on their beha-lf, and the core enterprises that suffer losses will not havethe motivation to continue to maintain cooperative relationswith farmers. Generally speaking, in order to obtain maxi-mum benefits and avoid risks to the greatest extent, core-enterprises are more inclined to choose farmers with betterqualifications as cooperative objects, and lack the willingn-ess and enthusiasm to cooperate with poor farmers, which greatly limits the income growth of poor farmers.

Traditional agricultural supply chain financial model: t-here are three kinds of typical "agricultural enterprises + farmers + financial institutions" mode, "agriculture enterprise+ park + farmers + financial institutions" mode, "agricultu-ral enterprise + cooperative + farmers + financial institute-ons" mode, the existing agricultural supply chain financialmodel mainly around the core enterprise to innovate, withthe development of information technology, agricultural sup-ply chainfinancial innovation to present three trends: onlin-e and offline integration development, platform and industrial integration, personalization and precision. As the agricu-ltural supply chain integration effect is not significant, risk con-trol ability is poor, all kinds of agricultural institutions of agricultural supply chain financial understanding and the u-nderstanding is not enough balance, development is relativ-ely slow, its innovative application and comprehensive riskprevention and control ability remains to be promoted, andthere is still a gap in the demand for financial security of the ru-ral revitalization strategy.

TABLE I. NET RECEIVABLES FROM INDUSTRIAL ENTERPRISES ABOVE SCALE

\begin{tabular}{|c|l|l|l|l|l|l|l|}
\hline & \multicolumn{6}{|c|}{ Net receivables from industrial enterprises above scale } \\
\hline Year & 2012 & 2013 & 2014 & 2015 & 2016 & 2017 & 2018 \\
\hline $\begin{array}{c}\text { Amoun } \\
\text { t(One } \\
\text { trillion } \\
\text { yuan) }\end{array}$ & 8.4 & 9.7 & 10.7 & 11.7 & 12.7 & 13.6 & 14.3 \\
\hline
\end{tabular}

a. Source of data: National Bureau of Statistics of China.

TABLE II. SIZE AND ForECAST OF CHINA SUPPLy CHAIN FINANCIAL MARKET 2015-2020

\begin{tabular}{|c|c|c|c|c|c|c|}
\hline \multirow[b]{2}{*}{ Year } & \multicolumn{6}{|c|}{$\begin{array}{c}\text { Size and Forecast of China Supply Chain Financial } \\
\text { Market 2015-2020 }\end{array}$} \\
\hline & 2015 & 2016 & 2017 & 2018 & 2019 & 2020 \\
\hline $\begin{array}{c}\text { Amount( } \\
\text { One } \\
\text { trillion } \\
\text { yuan) }\end{array}$ & 11.97 & 12.95 & 14.42 & 17.5 & 22.18 & 27.01 \\
\hline
\end{tabular}

a. Source of data: open data collation

TABLE III. AGRICULTURE-RELATED LOANS

\begin{tabular}{|c|l|l|l|l|l|l|l|}
\hline & \multicolumn{7}{|c|}{ Agriculture-related loans } \\
\hline Year & 2007 & 2008 & 2010 & 2012 & 2014 & 2016 & 2018 \\
\hline $\begin{array}{c}\text { Amoun } \\
\text { t(One } \\
\text { trillion } \\
\text { yuan) }\end{array}$ & 6.1 & 6.9 & 11.8 & 17.6 & 23.6 & 28.2 & 32.7 \\
\hline
\end{tabular}

a. Source of data: China Rural Finance Service Report 2018

\section{THE NECESSITY OF DEVELOPING AGRICULTURAL SUPPLY CHAIN FINANCE}

\section{A. To meet the demand for funds for the development of agricultural industry chain}

Agricultural industry chain development by expanding the agricultural industry chain development, promote the construction of agricultural whole industry chain, to changethe status quo of low value-added agriculture itself, the c-omprehensive agricultural planting, processing, services of resources integration, make the rural areas and farmers in the integrated supply chain to obtain more profits, especia-lly, its development needs the money and financial support,the agricultural supply chain finance enable farmers fast tr-ack sale of accounts receivable, inspire enthusiasm famersagricultural industry development, promote the healthy dev-elopment of the agricultural industry benign. 


\section{B. Play a major role in targeted financial poverty alleviation and rural revitalization}

The strategy of rural revitalization, as the main approa-ch to solve the problems of agriculture, the country-side and farmers in the new era, is the core component of achieving the strategic goals of rural revitalization, extendingthe industrial chain, upgrading the value chain and impro-ving the chain of interests. Based on actual order agricult-ural production and trade of agricultural supply chain fina-nce, the farmers financing business endorsement, the adva-ntages of the closed loop operation of funds, through thesupply chain finance make high risk individuals into a wh-ole chain of controllable risk, alleviate farmers financingpredicament, by reducing the uncertainty of the link betw-een supply and demand of agriculture and increasing eco-nomies of scale of agricultural production, improve the a-bility of poor farmers' production and in-come level, impr-oving the ability to repay capital and interest has promoted the development of inclusive finance in rural areas.

\section{THE CURRENT AGRICULTURAL SUPPLY CHAIN FINANCIAL DEVELOPMENT DIFFICULTIES}

\section{A. Agricultural products are non-standardized, with low stability and limited design of supply chain financial products}

As non-standardized products, the quality of raw materials, natural climate and temperature conditions, the use and control of cold chain logistics technology and other factors will affect the quality of agricultural products, it is difficult to maintain thevalue of agricultural products, the greater the degree of vol-atile prices of agricultural products, the market risk to t-he financial institutions into the credit funds, to the agric-ultural supply chain financial participation willingness willbe lower. Due to the nonstandardized conditions of agric-ultural products, it is difficult to implement future right fi-nancing and warehouse financing in supply chain products.Agricultural products cannot exist in the form of inventoryfor a long time, so they cannot be bought back. As agricu-ltural products are more difficult to preserve, financing wa-rehouse financing is not feasible.

\section{$B$. The credit risk system is not perfect}

Agricultural enterprise scale is small, the management is not standardized and the financial authenticity is low, management personnel credit consciousness, make the agricultural enterprise credit rating is low, there is credit risk, the agr-icultural enterprise, logistics enterprises, wholesale $\mathrm{r}$ - etailers,information asymmetry between Banks, lagging informationdistortion or information will result in either party decisio-n is unreasonable, contract compliance risk. At present, Ch-ina's credit evaluation system is not perfect, and the credit-rating of Alibaba, Jingdong and other companies based onbig data of ecommerce transactions is still limi-ted to th-eir own commercial systems, which makes it dif-ficult forcommercial Banks to make use of these credit data for c-redit risk assessment.

\section{Laws and policies are not sound enough}

China's supply chain finance started late, and the exist-ing policies reflect more principles and directional provisi-ons The content of development model and risk preventi-on is not perfect, and the policy of benefiting agriculture, supporting agriculture and strengthening agricul-ture is stru-cturally imperfect. The legal system is not sound enough, different regions have different efficiency in law enforce-ment, and the categories of law and government administ-rative power are indistinct. As a result, the order of finan-cial market cannot be fully regulated and guaranteed, and there are still many obstacles in the actual operation.

\section{The information system is not sound, and financial services are inefficient}

With the joint efforts of government departments and telecom enterprises, broadband and $4 \mathrm{G}$ networks have beenpopularized in rural areas. However, the Internet penetrationrate in rural areas grows slowly, and there is still a large gap bet-ween urban and rural Internet penetration rates (Table 4). And the informatization supervision and governance level of f-inancial management of agricultural supply chain are low.Vertically, the agricultural supply chain has a long chain,horizontally, there are many participants at the sam-e node,and the application of agricultural automation and data is insufficient, which makes it difficult to apply the big datamining model and leads to the weak comprehen-sive appl-ication ability of supply chain finance. Farmers' profession-al quality is insufficient, the application of comp-uter net-work technology is limited, the audience coverage of sup-plychain financial products is insufficient it is difficult to fully promote the application.

TABLE IV. 2014-2018 INTERNET PENETRATION IN URBAN AND RURAL AREAS OF CHINA

\begin{tabular}{|c|c|c|c|c|c|}
\hline & \multicolumn{5}{|c|}{ 2014-2018 Internet Penetration in Urban and Rural } \\
Areas of China & $\mathbf{2 0 1 6}$ & $\mathbf{2 0 1 8}$ \\
\hline Year & $\mathbf{2 0 1 4}$ & $\mathbf{2 0 1 5}$ & $\mathbf{2 0 1 6}$ & $\mathbf{2 0 1 7}$ & $75 \%$ \\
\hline Urban areas & $63 \%$ & $66 \%$ & $69 \%$ & $71 \%$ & $38 \%$ \\
\hline Rural areas & $29 \%$ & $32 \%$ & $33 \%$ & $35 \%$ & a. Source of data: open data collation.
\end{tabular}

\section{Strategic Policy Suggestions ON SUPPLY CHAIN FINANCE FOR RURAL REVITALIZATION}

\section{A. Financial product innovation and commercial ecological innovation}

Combined with the use of new Internet technologies, t-he design of credit products should be innovated to impro-ve the cycle matching degree between products and industrial development. Meanwhile, the overall managem-ent ab-ility of customized and fragmented products should be im-proved to meet the needs of rural credit microfinance andhigh frequency. Provide corresponding supply chain financ-ial products for different types of agricultural products. Atthe same time, we should improve the diversification levelof financing channels and related 
service institut-ions, intr-oduce financial partners and broaden financing channels. Agricultural supply chain ex-tends from core enterprises torelated industries, such as e-commerce, logistics and distri-bution, so as to promote the close contact between relatedindustries and form an industrial ecosystem. The governm-ent should grasp the basic access conditions of green, en-vironmental protection and sustainable industry, and givepreferential policies such as land and tax, so that industri-al and commercial capital can focus on the industrial development in rural areas and integrate into the local business ecology.

\section{B. Giving play to the leading role of the government and building a service-oriented government}

Government to innovation on the agricultural supply chain financial infrastructure management and service system,strengthen the agricultural supply chain finance each parti-cipation main body credit consciousness of education and training, better play a role of guidance, actively improve agricultural supporting infrastructure construction, strengthenthe farmer vocational education and the supply chain rela-ted knowledge training, and coordinate related governmentdepartments and the local branch of the people's bank, fi-nancial institutions, such as the court as soon as possibleand improve the farmers credit reporting system, perfect thesocial credit system, to strengthen the disciplinary mechan-ism construction, promote the rural credit system construc-tion. We will increase investment in agricultural infrastruct-ure, ensure that financial institutions serve the safety of agricultural production, and protect agricultural production.We will carry out education at various levels and in vari-ous categories in rural areas, run smallscle schools in rur-al areas, speed up the popularization of senior middlescho-ol education, and cut off the intergenerational transmissionof poverty, so as to foster both aspiration and wisdom.

Government adjust measures to local conditions impro-ve agricultural support policies, regulate and improve thefarmers' professional co-operatives, such as the developme-nt of new type of agricultural management main body pa-ttern, with the aid of inclusive finance products and services,to do a good job of start the poor peasant househ-olds to join the agricultural supply chain finance, stimulate intern-al momentum poor peasant households, which form the v-irtuous cycle of agricultural production, promote agricultur-al industrialization pattern step by step. We will improvepolicies such as premium subsidies and guarantee subsidies,actively promote agricultural insurance and agriculture-rela-ted guarantees, and provide assistance to poor groups whoare unable to work and are impoverished by ill-ness. We will support enterprises that actively undertake social resp-onsibility, and encourage and reward outstanding enterpris-es through the establishment of a sound supervision system,so that they will have the motivation to continuously ser-ve the rural areas in the fields of inclusive finance and p-overty alleviation.

\section{Applying new science and technology to promote industrialization}

Advanced technologies are widely used in agriculture, smart agriculture is developed, data transparency is enhan-ced, and multi-party monitoring and dynamic risk control are strengthened. System using big data analysis of global agricultural production process, build the data model, acc-urately grasp the dynamic economy and market trends, forfarmers or agricultural base the planting and breeding time,composition of soil, fertilization information such as howmuch precision guidance, precision production, understand the rival product data, reasonably adjust product structure, to differentiate the production. Based on the accumulated multidimen-sional data of upstream and downstream enter-prises and other transaction data on the Internet, it is co-mprehensively applied to the risk control before, during a-nd after lending by means of data model analysis and da-ta crossvalidation, reduce information fraud and moral hazard. Industrial Internet should be built through the introduction of intelligent management system, in accordance withthe division of labor in agriculture and different levels of technology, professional outsourcing services should be formed so that professional people can do professional things.

\section{Build a resource-sharing ecosystem}

Strengthen rural especially remote and poor area communication network and development of the modern logis-tics system, in the field of agriculture, rural areas and far-mers to implement a complete coverage of the Internet, t-he Internet of things, the innovative construction of agric-ultural supply chain information sharing mechanism, const-ructing sharing platform, solve the problem of asymmetric information, integration of logistics companies and socialdrivers, idle resources, make full use of social idle vehicl-es Shared vehicles, logistics transport industry to reduce c-osts, increase the industrial chain upstream and downstrea-m enterprise profits. Establish industry standards, let the p-roduction standards of agricultural products deep processin-g plant to join the platform, sharing processing plant, bro-aden the raw material purchase channels, establish a stablesales relationship. Establish communi-cation channels betw-een warehouse operators and agriculture-related enterprises and farmers, share warehouses, solve the storage problemsof agricultural products, and improve the utilization rate ofwarehouses.

\section{E. Strengthening the legal guarantee of agricultural supply chain finance}

We will further extend and revise existing laws and $\mathrm{p}$ olicies, improve basic laws and policies in this field, and develop a complementary set of laws and policies. Improv-e the agricultural insurance mechanism and industry tradi-ng system, and constantly broaden the content of the gua-rantee business, promote rural resources and financial reso-urces effectively and transformation, strengthen the govern-ment's policy support, reasonable use financial leverage, a-llow it to break through the current policy appropriately,explore new models of innovation of supply chain financeservice rural revitalization of perfecting rural financial leg-al system in China. 


\section{CONCLUSION}

Agricultural supply chain finance mode has realized th-e transformation of rural finance from decentralized to centralized, alleviated the long-standing financing difficultiesin the field of rural finance, improved the financial availa-bility of poor farmers, and promoted the large-scale opera-tion and industrialization development of agriculture. The e-fficient development of agricultural supply chain finance c-an effectively link the government, enterprises, financial i-nstitutions and farmers with the joint efforts of all sectorsof society to help fight against poverty, stim-ulate the endogenous driving force of rural development, and acceleratethe realization of rural revitalization strategy.

\section{ACKNOWLEDGMENT}

On the occasion of the completion of the thesis, I would like to thank the teacher for my guidance and help, thank my classmates for their support and encouragement, thank my roommates for my care and care, there are too many people who have helped me, sincerely thank all the people who care and help me. This article refers to a large number of literature, here, to pay tribute to the academic predecessors.

\section{REFERENCES}

1. Yun Shen. "Social Capital, Dual Finance and Peasant Household Borrowing Behavior,” Economic Review,2016, pp. 80-90.

2. Yanjie Gou. "The Innovation of Financial Model for Agricultural Supply Chain," Journal of Sichuan University of Science \& Engineering(Social Sciences Edition),2020, pp. 33-52.

3. Michael Lamoureux. "A supply chain finance prime," Supply Chain Finance,2007, pp. 34-48

4. Tina Breckwoldt. "Management of Grain Storage in Old Babylonian Larsa," Archiv für Orientforschung,1995, pp. 42-43.

5. Miller, Calvin, Jones, Linda. "Agricultural value chain finance: tools and lessons," Agricultural Value Chain Finance Tools \& Lessons, 2010.

6. Longyao Zhang, Yuyun Xu, Bing Zhang. "In- kind finance substitute mechanism for failure of rural credit market: a case study of Jiangsu Province," Journal of Southeast University (Philosophy and Social Science),2018, pp. 60-69.

7. Ziqiang Zhang, Guoyong Wu, Ping XU. "Logic Reconstruction of Rural Household Poverty in Ethnic Areas: the Perspective of Vicious Circle of Poverty," Guizhou Ethnic Studies,2017, pp. 69 72.

8. Donghui Jiang, Bo Wang. "Accurate and Inclusive Finance: The Innovation and development of Agricultural Supply Chain Finance," Rural Economy,2020, pp. 99-104

9. Jiujie Ma, Xing Luo, BenJian Wu. "Research on the Innovation of poverty alleviation mechanism of precision financial industry," Contemporary Rural Finance and Economics,2016, pp. 26-29+37.

10. Yun Shen, Xiaobing Peng. "Chain Financing Model and the Effects of Precision Poverty Alleviation: Empirical Study Based on Quasi Experiment," Journal of Finance and Economics,2016, pp. 4-15. 